\title{
Serotonin and Insulin Release in vitro
}

\author{
M. Telib, S. Raptis, K.E. Schröper and E.F. Pfeifher* \\ Department of Clinical Endocrinology and Metabolism, Centre of Medicine, University of UIm/Donau \\ Received: February 3, 1968
}

\begin{abstract}
Summary. Serotonin stimulated insulin release, independently of glucose, from rabbit pancreatic tissue in vitro. A concentration of $100 \mu \mathrm{g} / \mathrm{ml}$ gave a maximal insulin release. Higher concentrations delayed insulin release. The simultaneous incubation with serotonin and glucose led to a slight decrease in insulin release. This decrease in insulin release rose with increasing serotonin concentrations. - The insulin production induced by serotonin stimulation $(100 \mathrm{\mu g} / \mathrm{ml})$ was quantitatively equivalent to the maximal amount of insulin released by $2 \mathrm{mg}$ glucose per $\mathrm{ml}$, and by $1 \mathrm{mg}$ of tolbutamide per $\mathrm{ml}$. - The sig. nificance of these findings with regard to the difference in the results obtained with the oral as compared with the intravenous glucose tolerance test, and with respect to the pathogenesis of both the dumping and the carcinoid syndromes were discussed.
\end{abstract}

\section{Sérotonine et libération d'insuline in vitro}

Résumé. La sérotonine stimule la libération de l'insuline par le pancréas du lapin in vittro indépendamment du taux du glucose dans le milieu d'incubation. La concentration de $100 \mu \mathrm{g} / \mathrm{ml}$ provoqua une sécrétion insulinique maximale. Des concentrations plas élevées inhibaient la sécrétion d'insuline. L'incubation simultanée avec sérotonine et glucose causa une diminution légère de la sécrétion insulinique. Cette diminution augmentait quand la concentration de sérotonine augmentait. L'effet de $100 \mu \mathrm{g} / \mathrm{ml}$ de sérotonine était comparable à l'effet do
$2 \mathrm{mg} / \mathrm{ml}$ de glucose ou de $1 \mathrm{mg} / \mathrm{ml}$ de tolbutamide. La signification de ces observations en vue d'expliquer la différence entre les résultats obtenus avec le test de tolérance au glucose par voie orale et par voie intraveineuse a été discutée ainsi que leur signification dans la pathogénie du dumping -syndrome et du syndrome du carcinoïde.

\section{Serotonin and Insulinfreisetzung in vitro}

Zusammenfassung. Serotonin stimuliert die Insulinfreisetzung aus dem Kaninchenpankreas in vitro unabhängig vom Glucosespiegel im Inkubationsmedium. Die Konzentration von $100 \mu \mathrm{g} / \mathrm{ml}$ führte zu einer maximalen Insulinausschüttung. Höhere Konzentrationen hemmten die Freisetzung des Insulins. Die gleichzeitige Inkubation mit Serotonin und Glucose rief eine geringfügige Verminderung der Insulinsekretion hervor. Diese Verminderung nahm mit steigender Serotoninkonzentration zu. - Die nach Stimulierung mit Serotonin $(100 \mathrm{\mu g} / \mathrm{ml})$ ausgeschüttete Insulinmenge entsprach der nach Zusatz von $2 \mathrm{mg}$ Glucose $/ \mathrm{ml}$ und $1 \mathrm{mg}$ Tolbutamid $/ \mathrm{ml}$ sezernierten. Die Bedeutung dieser Befunde für das Verständnis der unterschiedlichen Ergebnisse nach oraler und intravenöser Glucosebelastung wurde ebenso diskutiert wie ihre Bedeutung für die Pathogenese von Dumping- und KarzinoidSyndrom.

Key-words: Serotonin, insulin secretion in vitro, Carcinoid, Dumping.
The insulin concentration in the serum following a glucose load in a tolerance test is higher when the glucose is given orally than when it is given intravenously, and this difference is attributed to the pres. ence of insulin-releasing substances in the mucous membrane of the gastro-intestinal tract. Among these are secretin (Mc INTYRE et al., 1965; PFEIFFER et al., 1965; Bottermary et al., $1967 \mathrm{a}$ and $b$; Raptis et al., 1967) glucagon and pancreozymin (LANGS and FrIEDBeRg, 1965; SaMmols etal., 1965; Meade etal., 1967; ScHRöDER et al., 1967; UnGER etal., 1967).

Serotonin is present in abundant amounts in the small intestine, in particular in the duodenum and the jejunum (Ersparrar, 1953, 1954, Toвe et al., 1966); and it is involved in carbohydrate metabolism (KoBAYASHI et al., 1960); thus raising the question whether it may belong to these gastro-intestinal hormones that stimulate insulin release. A glycogenetic effect of serotonin, discussed by Ur in 1962 was attributed to serotonin-mediated secretion of endogenous pancreatic insulin.

The present paper deals with the effect of serotonin on the insulin secretion of isolated pancreatic tissue,

* Supported in part by Deutsche Forschungsgemeinschaft, Bad Godesberg (Pf $38^{\circ} 23$ ). continuing and extending the first communication of one of us (PFEIFFER) to the VI Congr. Intern. Diab. Fed., Stockholm 1967.

\section{Method}

Part of the method has been published elsewhere (TeLIB etal., 1966). Male rabbits weighing about $2-3 \mathrm{~kg}$ and fasted overnight, were killed with sodium barbitol; the pancreas was immediately removed, placed in cold physiologic saline $(0.9 \mathrm{giNaCl} / 100 \mathrm{ml})$, and cleaned of all blood vessels and fat. The thick portion of the caudal part of the pancreas was cut with a Stadie-Riggs Microtome to give a thin layer of tissue of about $0.5 \mathrm{~mm}$. The pancreatic pieces were incubated in $4 \mathrm{ml}$ of Krebs-Ringer bicarbonate, supplemented with the sodium salts of pyruvic, glutamic and fumaric acids (CoOre and RaNDLe, 1962, 1964; TeLIB, 1968). After a preincubation period of $30 \mathrm{~min}$, the tissue was incubated in buffer with the following constitution:

1. buffer alone for measuring basic secretion; 2. buffer with a glucose concentration of $200 \mathrm{mg} \%$;

3. buffer with tolbutamide as a comparative stimulant; 4. buffer with varying amounts of 5-hydroxytryptamine (serotonin). 
After the incubation period, the insulin content of the medium was measured with the rapid radio-immunological method (Tetis and Pfeifferer, 1968).

\section{Results}

Fig. 1 shows the effect of the different serotonin concentrations on insulin release in vitro. A concentration of $10 \mu \mathrm{g} / \mathrm{ml}$ gave a significant rise in insulin release

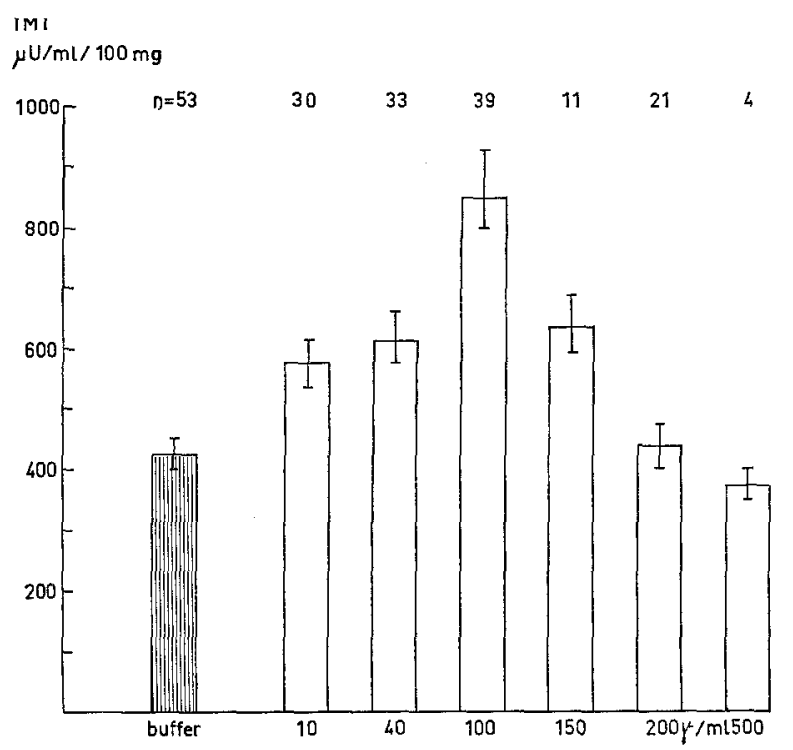

Fig. 1. Effect of different concentrations of serotonin on insulin release from rabbit pancreatic tissue in vitro

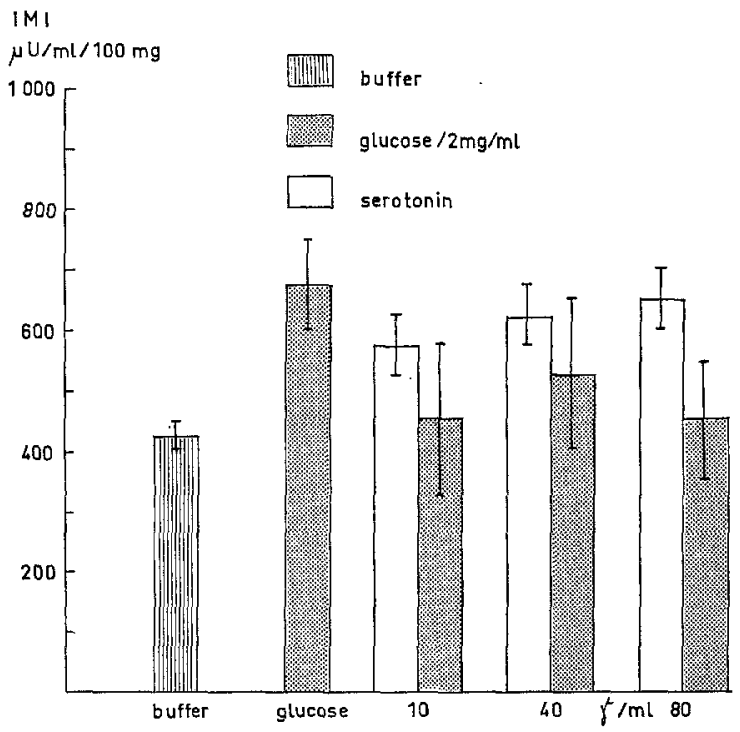

Fig. 2. Effect of serotonin on the stimulatory effect of glucose on insulin release from pancreatic tissue of rabbit in vitro

over the basal value; i.e. $440 \pm 32 \mu \mathrm{U}$ of insulin per $\mathrm{ml}$ with buffer alone, and $574 \pm 55 \mu \mathrm{U} / \mathrm{ml}$ with $10 \mu \mathrm{g}$ of serotonin per ml. Increasing the concentration of serotonin led to no further significant increase in in- sulin secretion. Although a 10 -fold increase in serotonin concentration gave a significantly higher increase in insulin release, raising the concentration to $500 \mu \mathrm{g} / \mathrm{ml}$ led not only to no further increase, but in fact gave a significant inhibition of insulin release. Expressed as percent of the effect with the buffer alone (basal value, $100 \%$ ), the $10 \mu \mathrm{g} / \mathrm{ml}$ concentration gave an increase $130 \%$; the $100 \mu \mathrm{g} / \mathrm{ml}, 200 \%$; with $200 \mu \mathrm{g} / \mathrm{ml}$ there was a drop to $105 \%$, and with $500 \mu \mathrm{g} / \mathrm{ml}$ a further drop

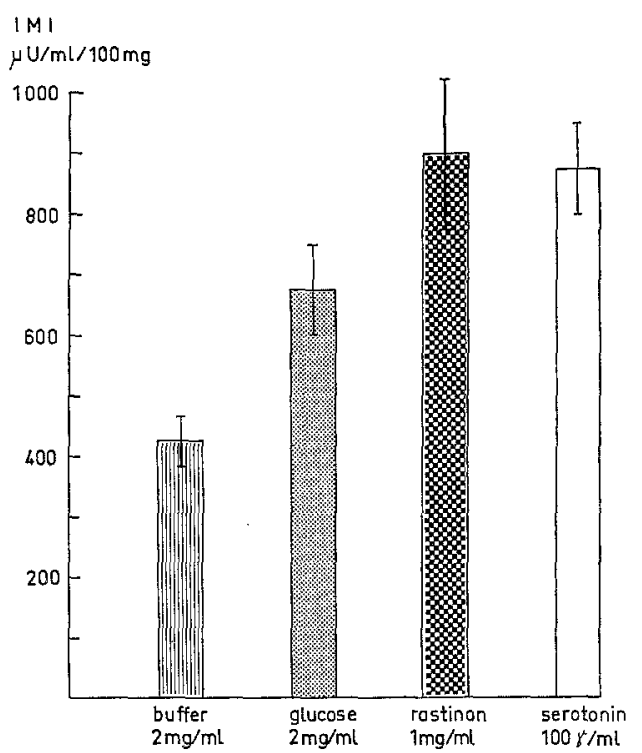

Fig. 3. Comparison of effect of serotonin $(100 \mu \mathrm{g} / \mathrm{ml})$ with that of glucose and rastinon on insulin release from rabbit pancreas in vitro

to $75 \%$. The combination of glucose $(200 \mathrm{mg} \%)$ and serotonin (Fig. 2) gave no additional effect on insulin release, and in fact there was a decrease in insulin release compared with glucose or serotonin alone. Fig. 3 illustrates the comparison between the effect of the optimal concentrations of serotonin, glucose $2 \mathrm{mg} / \mathrm{ml}$ and tolbutamide $1 \mathrm{mg} / \mathrm{ml}$. The effect of $100 \mu \mathrm{g}$ of serotonin per $\mathrm{ml}$ was more or less the same as that of $1 \mathrm{mg}$ of tolbutamide.

\section{Discussion}

The data presented here seem to verify the postulate of Ur, (1962) that serotonin stimulates insulin secretion. This stimulating effect, as shown from our results in vitro, may be assumed to be a physiological one. WEst (1958) pointed out that pancreas possesses 5-hydroxytryptophan-decarboxylase activity, which is the enzyme forming serotonin from 5 -hydroxytryptophan, and that monoamine oxidase activity, though found in pancreatic tissue as well (FALCK and HELIMANN, 1964) was much lower than 5-hydroxytryptophan decarboxylase. His finding appears to suggest the existence of serotonin in pancreatic tissue in fairly large amounts. Using a fluorescent microscopical method, FalcK and Heldmann, (1964) and DaYan 
(1967) have shown that in several species, but not in man, the $\gamma$-cells of the islets of Langerhans contain 5 -hydroxytryptamine. Besides its presence in the $\beta$ cells, it is abundant in the small intestine, especially the duodenum of many mammals (PENTILLÄ, 1966).

The fact that oral glucose tolerance leads to a higher insulin value in serum than does the intravenous one, is explained by many authors to be due to the presence of intestinal hormones secreted from the duodenal mucous membrane, which act either directly or indirectly on the pancreas. Some of these hormones have already been tested for insulin release in vivo (SAmoLs et al., 1965; Srmpsor et al., 1966; Melant et al., 1967; PFEIFHER, 1967; RAPTIS et al., 1967; RuPTIS et al., 1968; UNGer et al., 1967) and in vitro (PFEIFFER et al., 1965; TeLIв et al., 1966; SchrödER et al., 1967; TURNer et al., 1966; TEuIB 1968).

Another support for the serotonin-insulin relationship may be derived from the fact that after intravenous injection of growth hormone, serotonin is released in the pancreatico-duodenal vein (GALANSINo et a1., 1963; STREK et al., 1966); and after growth hormone injection, there is also a rise in insulin release (Pfeiffer et al., 1964; Melani in our laboratory unpublished data). Thus it may be, that the serotonin, which is released following the growth hormone injection, is responsible for the release of insulin.

The effect of serotonin on the blood sugar remains a matter of controversy. Hyperglycaemic (SIREK et al., 1957; Colombo et al., 1960; Galansino et al., 1960) as well as hypoglycaemic (Mrrsky et al., 1957; KoBYASHI et al., 1960) actions have been discussed. In support of the latter conclusion are the clinical symptoms which accompany both the dumping and the carcinoid syndromes. In both there is an elevation of 5-hydroxytryptamine in blood, and in most cases a marked fall in blood sugar was observed (Draparas et a1., 1962; Peart et al., 1963; VAN DER SLUYs VeER et al., 1964; ZuITun and SNITH, 1966). On the other hand after serotonin injection a rise in non-esterified fatty acids (NEFA) in serum was found (CARLSON et al., 1967), suggesting a lipolytic effect of serotonin in vivo. However this effect was not demonstrated in vitro (ITAYA and UI, 1964; BIECK et al., 1966). It is therefore possible, that serotonin, when administered in vivo may stimulate the mobilization of NEFA, not by a direct effect of its own on adipose tissue, but indirectly through the liberation of other hormones. For example, the liberation of epinephrine, which is responsible for the hyperglycaemia resulted after a hypoglycaemic phase due to insulin release in an intact rat, since no hyperglycaemia was observed in an adrenomedullated one (KoвaYASII et al., 1960). The lipolytic effect of serotonin may not be seen under normal conditions due to the fact that the amine is rapidly metabolized in adipose tissue by monoaminoxidase. It is interesting to note that 3,5-AMP, which stimulates insulin release (WIIIAMS and ENSINCK, 1966), is formed from serotonin (Breck et al., 1966).

\section{References}

Breck, P., K. Stock, and E. Westrermann: Lipolytic action of serotonin in vitro. Life Sciences 5, 2157-2163 (1966).

BottermanN, P., A. Souvatzoglou u. K. Schwarz: Stimulierung der $\beta$-eytotropen Wirkung von Tolbutamid durch Sekretin beim Menschen. Klin. Wschr. 10, 549550 (1967a).

- K. Schwarz, M. M. Foreld, H. Stahtberger u. A. SoUvatzogrod: Stimulierung der Insulinsekretion durch Sekretion beim Menschen. Klin. Wschr. 1, 52-53 (1967 b).

Carlson, L.A., L.G. Ekelund, and L. Orö: Metabolic and cardiovascular effects of serotonin. Life Sciences 6 , $261-271(1967)$

Colombo, J.P., J.W. Weber, G. GuIdotri, D. KanaMEISHX, and P.P. FOA: Liver phosphorylase in normal and adrenalectomized dogs treated with serotonin. Endocrinology 67, 693-697 (1960).

CoORF, G., and P.J. RANDLE: Secretion of insulin by rabbit pancreas. Biochem. J. 84, 78 p (1962).

- - Regulation of insulin secretion studied with pieces of rabbit pancreas. Biochem. J. 93, 65-78 (1964).

DAYAN, A.D.: Absence of catecholamines from islet cells of human pancreas and a $\beta$-cell tumor in man. Acta Histochem. 28, 186-188 (1967).

Drapanas, T., J.C. McDoNatd, and J.D. Stewart: Serotonin release following instillation of hypertonic glucose into the proximal intestine. Ann. Surg. 156, $528-536$ (1962).

Erspamer, V.: Über den 5-Hydroxytryptamin (Enteramin) Gehalt des Magen-Darm-Traktates bei den Wirbeltieren. Naturwiss. 40, 318-319 (1953).

- Quantitative estimation of 5-Hydroxytrytamine in gastrointestinal tract, spleen and blood of vertebrates. In: Ciba Found. Symp. on Hypertension, 78-84. Ed. G.E.W. Wolstenholme and M.P. Cameron. London: J. \& A. Churchill, 1954.

Falck, B., and B. Hellimann: A fluorescent reaction for monoamines in the insulin producing cells of the guinea. pig. Acta endocr. (Kobenhavn) 45, 133-138 (1964).

Galansino, G., G.D. Amico, D. Kanaineisht, F.G. BerIINGER, and P.P. Fò̀: Hyperglycemic substances originating in the pancreaticoduodenal area. Amer. J. Physiol. 198, 1095-1062 (1960).

- R. Litta-Modignani, F. Berlinger, D. Billinger, and P.P. FoA: Studies on the release of serotonin and eatecholamines in the pancreaticoduodenal area. Proc. Soc. exp. Biol. 112, 542-544 (1963).

ItAVA, K., and M. UI: The inhibitory action of serotonin in free fatty acid utilization by rat mesenteric adipose tissue. Biochim. biophys. Acta 84, 604-606 (1964).

KobaYashi, B., M. UI, and J. Warashina: The role of serotonin in carbohydrate metabolism. I. Glycemic effect of serotonin in rats. Endocr. jap. 7, 225-238 (1960).

- M. UI, and J. WARAshINa: IT. The effeet of serotonin on glycogen content of liver, heart and diaphragm in rats. Endocr. jap. 7, $239-248$ (1960).

LANGS, H.M., and D. FrIedBerg: Stimulation of insulin secretion by glucagon. Clin. Res. Proc. 13, 548-549 (1965).

MoIntyre, N., D.S. Turner, and C.D. Holdswortm: Intestinal factors and insulin secretion (Abstr.) Diabetologia 1, 73 (1965).

Meade, R. C., H. A. Knaubuhler, W.J. Schults and J.J. BARBORIAK: Stimulation of insulin secretion by pancreozymin. Diabetes 16, 141-144 (1967).

Merani, F., J. Laweckr, K. M. Bartelt, and E.F. PeEtFFER: Immunologisch meßbares Insulin (IMI) bei Stoffwechselgesunden, Fettsüchtigen und Diabetikern nach 
intravenöser Gabe von Glucose, Tolbutamid und Glukagon. Diabetologia 3, 422-426 (1967).

Mrrsky, A.L., G. Perisutit, and R. Jinks: The hypoglycemic action of metabolic derivatives of L-tryptophan by mouth. Endocrinology 60, 318-324 (1957).

Pearr, W.S., K.A. Proter, J.I.S. Robertson, M. SandLER, and E. BALDOCK: Carcinoid syndrome due to pancreatic-duct secreting 5-Hydroxytryptophan and 5Hydroxytryptamine. Lancet 1963 1, 239-242.

Pentillä, A.: Histochemical reactions of the enterochromaffin cells and the 5-Hydroxytryptamine content of the mammalian duodenum. Acta physiol. scand. 69, suppl. 281 (1966).

PFEIFFER, E.F.: Wachstumshormon und Insulinsekretion. Die Verhältnisse unter normalen und pathologischen Bedingungen. 11. Symp. Dtsch. Ges. für Endocrinol. in Düsseldorf, 41 (1964).

- Intestinal factors controlling insulin secretion. $6^{\text {th }}$ Congr. Intern. Diab. Fed., Stockholm, 1967 (in press)

- M. Telib, J. Amimon, F. Melani u. H. Ditschuneit : Direkte Stimulierung der Insulinsekretion in vitro durch Sekretin. Dtsch. med. Wschr. 90, 1663-1669 (1965).

Raptis, S., K.E. Schröder, F. Melani, J. Beyer u. E.F. Pfeifrer: Die Stimulierung der Insulinselkretion durch Sekretin beim IMenschen. $6^{\text {th }}$ Congr. Intern. Diab. Fed., Stockholm, 1967 (in press).

- - M. Terts u. E. F. Pfeiffer: Unterschiede in der Wirkung des Sekretins bei Normalgewichtigen und Adipösen. Wioner Z. inn. Med. 1968 (in press).

Samols, E., G. Marri, and V. Marks: Promotion of insulin by glucagon. Lancet 1965 II, $415-416$.

Schröder, K.E., S. Raptis, M. Thlitb, and E.F. PheifFER: Intestinal hormone affecting insulin secretion in vitro: secretin, pancreozymin and gastrin. $6^{\text {th }}$ Congr. Intern. Diab. Fed., Stockholm, 1967 (in press).

Stmpson, R.C., A. Benedetiti, G.M. Grodsky, J.A. KARAM, and P.H. ForshaM: Stimulation of insulin release by glucagon in non-insulin-dependent diabetics. Metabolism 15, 1046-1049 (1966).

Strek, O.V., A. SIREK, and C.H. BEST: Pituitary growth hormone and the question of pancreatic secretion of glucagon. Amer. J. Physiol. 188, 17-20 (1957).

Sirer, A., E. Gefrlin, and O.V. Sirer: Serotonin as the hyperglycemic substance released by growth hormone. Amer. J. Physiol. 211, 1018-1020 (1966).

Texis, M. : Vergleichende Untersuchungen über den Einfluß von Monosacchariden und Hormonen auf die Insulinsekretion des isulierten Pankreasgewebes einiger Säugetiere und des Frosches. Z. ges. exp. Med. 147, $316-322$ (1968).
- F. Merani, H. Ditschuneit, J. Ammon u. E. F. PferfFER: Vergleichende Untersuchungen über die Beoinflussung der Insulinsekretion isolierter Pankreasgewebe durch Glukose, Tolbutamid, ACTH, STH, Glukagon und Sekretin. 12. Symp. Dtsch. Ges. Endocrinol., Wiesbaden, P 92 (1966).

- K.E. SChröder, S. Raptis, and E.F. PfenfFer: Stimulating effect of pancreozymin and gastrin on insulin release from isolated rabbit pancreas. (in prep.)

-, and E.F. PFEIFHER: A modified coated-charcoal immunoassay for measuring insulin release in vitro. (in press), 1968 .

Tobe, T., M. FuJtwara, and C. Raraka: Distribution of serotonin (5-Hydroxytryptamine) in the human gastro-intestinal tract. Amer. J. Gastroent. 46, 34-37 (1966).

TURNER, D.S., and N. MoINTYRE: Stimulation by glucagon of insulin release from rabbit pancreas in vitro. Lancet $1966 \mathrm{I}, 351-352$.

UI, M. : The role of serotonin in carcohydrate metabolism. VII. In vitro observations suggesting enhanced release of insulin in response to serotonin treatment. Endocr. jap. 9, 22-32 (1962).

Unger, R.H., H. KetTerer, J. Dupré, and A.M. Eisen TRANT: The effects of secretin, pancreozymin and gastrin on insulin and glucagon secretion in anesthetised dogs. J. clin. Invest., 46, 630-645 (1967).

van der Sluys Veer, J., J.C. Choufoer, A. Querido, R.O. VAN DER HeUL, C.F. HollaNder, and T.G. vaN RuJssec: Metastasising isletcell tumor of the pancreas associated with hypoglycaemia and carcinoid syndrome. Lancet 1964 II, $1416-1419$.

West, G.B.: 5-Hydroxytryptamine and hyperglycemia. Nature (Lond.) 182, 182 (1958).

WIILIAMs, R.H., and J.W. ENsINCK: Secretion, fates and actions of insulin and related products. Diabetes 15, $623-654(1966)$.

ZwITLIN, I.J., and A.N. SMITH: 5-Hydroxyindoles and kinins in the carcinoid and dumping syndromes. Lancet 1966 I, 986-991.

Requests for reprints to:

Universität Ulm Bibliothek des Zentrums

für Innere Medizin

$7900 \mathrm{Ulm}$ (Donau)

Steinhövelstr. 9 